\title{
Allopatric chromosomal variation in Nematocharax venustus Weitzman, Menezes \& Britski, 1986 (Actinopterygii: Characiformes) based on mapping of repetitive sequences
}

\author{
Silvia B. Barreto ${ }^{1}$, Marcelo B. Cioffi ${ }^{2}$, Aline S. Medrado ${ }^{3}$, André T. Silva ${ }^{4}$, \\ Paulo R. A. M. Affonso ${ }^{1}$ and Débora Diniz ${ }^{1}$
}

Characiformes is the most cytogenetically studied group of freshwater Actinopterygii, but karyotypical data of several taxa remain unknown. This is the case of Nematocharax, regarded as a monotypic genus and characterized by marked sexual dimorphism. Therefore, we provide the first cytogenetic report of allopatric populations of Nematocharax venustus based on distinct methods of chromosomal banding and fluorescence in situ hybridization (FISH) with repetitive DNA probes (18S and 5S rDNA). The karyotype macrostructure was conserved in all specimens and populations, independently on sex, since they shared a diploid number $(2 \mathrm{n})$ of 50 chromosomes divided into $8 \mathrm{~m}+26 \mathrm{sm}+14 \mathrm{st}+2 \mathrm{a}$. The heterochromatin was mainly distributed at pericentromeric regions and base-specific fluorochrome staining revealed a single pair bearing GC-rich sites, coincident with nucleolar organizer regions (NORs). On the other hand, interpopulation variation in both number and position of repetitive sequences was observed, particularly in relation to $5 \mathrm{~S}$ rDNA. Apparently, the short life cycles and restricted dispersal of small characins, such as $N$. venustus, might have favored the divergence of repetitive DNA among populations, indicating that this species might encompass populations with distinct evolutionary histories, which has important implications for conservation measures.

Characiformes é o grupo de Actinopterygii de água doce mais estudado citogeneticamente, porém dados cariotípicos de vários taxa permanecem desconhecidos. Este é o caso de Nematocharax, considerado um gênero monotípico e caracterizado pelo acentuado dimorfismo sexual. Em vista disso, nós fornecemos a primeira descrição citogenética de populações alopátricas de Nematocharax venustus, baseada em métodos distintos de bandamento cromossômico e hibridação fluorescente in situ (FISH) com sondas de DNA repetitivo (DNAr 18S e 5S). A macroestrutura cariotípica mostrou-se conservada em todos os espécimes e populações, independentemente do sexo, uma vez que compartilharam um número diploide $(2 \mathrm{n})$ de 50 cromossomos dividido em $8 \mathrm{~m}+26 \mathrm{sm}+14 \mathrm{st}+2 \mathrm{a}$. A heterocromatina distribuiu-se principalmente nas regiões pericentroméricas e a coloração com fluorocromos base-específicos revelou um único par portador de sítios GC-ricos, coincidentes com as regiões organizadoras de nucléolo (RONs). Por outro lado, foi observada uma variação interpopulacional no número e na posição das sequências repetitivas, especialmente em relação ao DNAr 5S. Aparentemente, ciclos de vida curtos e dispersão restrita dos pequenos caracídeos, tal como $N$. venustus, podem ter favorecido a divergência do DNA repetitivo entre as populações, indicando que essa espécie pode englobar populações com distintas histórias evolutivas, o que tem implicações importantes para medidas de conservação.

Keywords: $18 \mathrm{~S}$ rDNA, 5S rDNA, Coastal drainages, FISH, Population cytogenetics.

${ }^{1}$ Departamento de Ciências Biológicas, Universidade Estadual do Sudoeste da Bahia, Av. José Moreira Sobrinho, s/n, Jequiezinho, 45206-190 Jequié, Bahia, Brazil. (SBB) silvinhabbarreto@hotmail.com (corresponding author), (PRAMA) paulomelloaffonso@yahoo. com.br, (DD) debora.dinizb@gmail.com

${ }^{2}$ Departamento de Genética e Evolução, Universidade Federal de São Carlos, Rodovia Washington Luís, Km 235, s/n, Jardim Guanabara, 13565-905 São Carlos, São Paulo, Brazil. mbello.ufscar@gmail.com

${ }^{3}$ Departamento de Ciências Biológicas, Universidade Estadual de Santa Cruz, Rodovia Jorge Amado, Km 16, Salobrinho, 45662-900 Ilhéus, Bahia, Brazil. alinesmedrado@yahoo.com.br

${ }^{4}$ Departamento de Zoologia, Instituto de Biociências, Universidade Estadual Paulista Júlio de Mesquita Filho, Av. 24-A, 1515, Bela Vista, 13506-970 Rio Claro, São Paulo, Brazil. silva.at@gmail.com 


\section{Introduction}

The Neotropical freshwater ichthyofauna is remarkable by their richness, complexity and high endemism (Vari \& Malabarba, 1998). A great majority of fish species in this region belongs to the family Characidae, which includes at least 1,107 valid species (Eschmeyer \& Fong, 2015). However, the phylogenetic relationships and systematics of genera in this family are controversial, being several taxa placed as incertae sedis (Weitzman \& Fink, 1983). In addition, the identification of species complexes or cryptic species hinders a precise characterization of the diversity in this group (Kavalco et al., 2009; Castro et al., 2014a).

Accordingly, cytogenetic analyses have been carried out to address this issue, since chromosomal markers have proved to be useful for both systematic and evolutionary inferences in Neotropical fish (Blanco et al., 2010; Almeida et al., 2013; Piscor et al., 2015), including taxonomically problematic groups (Bellafronte et al., 2010; Mendes et al., 2011). Moreover, the availability of refined cytogenetic methods have allowed identifying population polymorphism and unique evolutionary units, even within morphologically similar groups (Bitencourt et al., 2011; Utsunomia et al., 2014).

Nematocharax Weitzman, Menezes \& Britski represents one of the several genera in Characidae whose taxonomic status is still under debate. This genus has been considered monotypic since the validation of Nematocharax venustus Weitzman, Menezes \& Britski (1986), originally described for the Jequitinhonha River basin, eastern Brazil. Recently, Bragança et al. (2013) reported a second species, named
N. costai, for the Contas River basin, northeastern Brazil, which was not widely accepted among ichthyologists. Hence, Menezes et al. (2015) carried out a detailed analysis of meristic, morphometric, osteological and coloration patterns of specimens from several hydrographic basins throughout the range of Nematocharax. According to these authors, N. costai is actually a junior synonym of $N$. venustus once overlapped morphological features and polymorphism of secondary sex traits in males were observed for both putative species, thereby supporting Nematocharax as a monotypic genus.

Based on the complex systematics and morphological variation of $N$. venustus, we performed comparative chromosomal analyses in allopatric populations of this species, including those previously recognized as $N$. costai in order to elucidate the taxonomic status of this fish group and infer biogeographic aspects in ichthyofauna from coastal basins of eastern Brazil. Therefore, distinct cytogenetic methodologies, ranging from basic banding techniques up to fluorescence in situ hybridization (FISH) experiments with repetitive DNA probes, were used to identify the karyotypic structure and possible population differences through the range of this species.

\section{Material and Methods}

A total of 71 males and 70 females of Nematocharax venustus were collected in seven localities along the Contas, Almada and Jequitinhonha River basins in the states of Bahia and Minas Gerais (Brazil) (Fig. 1). The data about collection sites and samples are shown in Table 1.

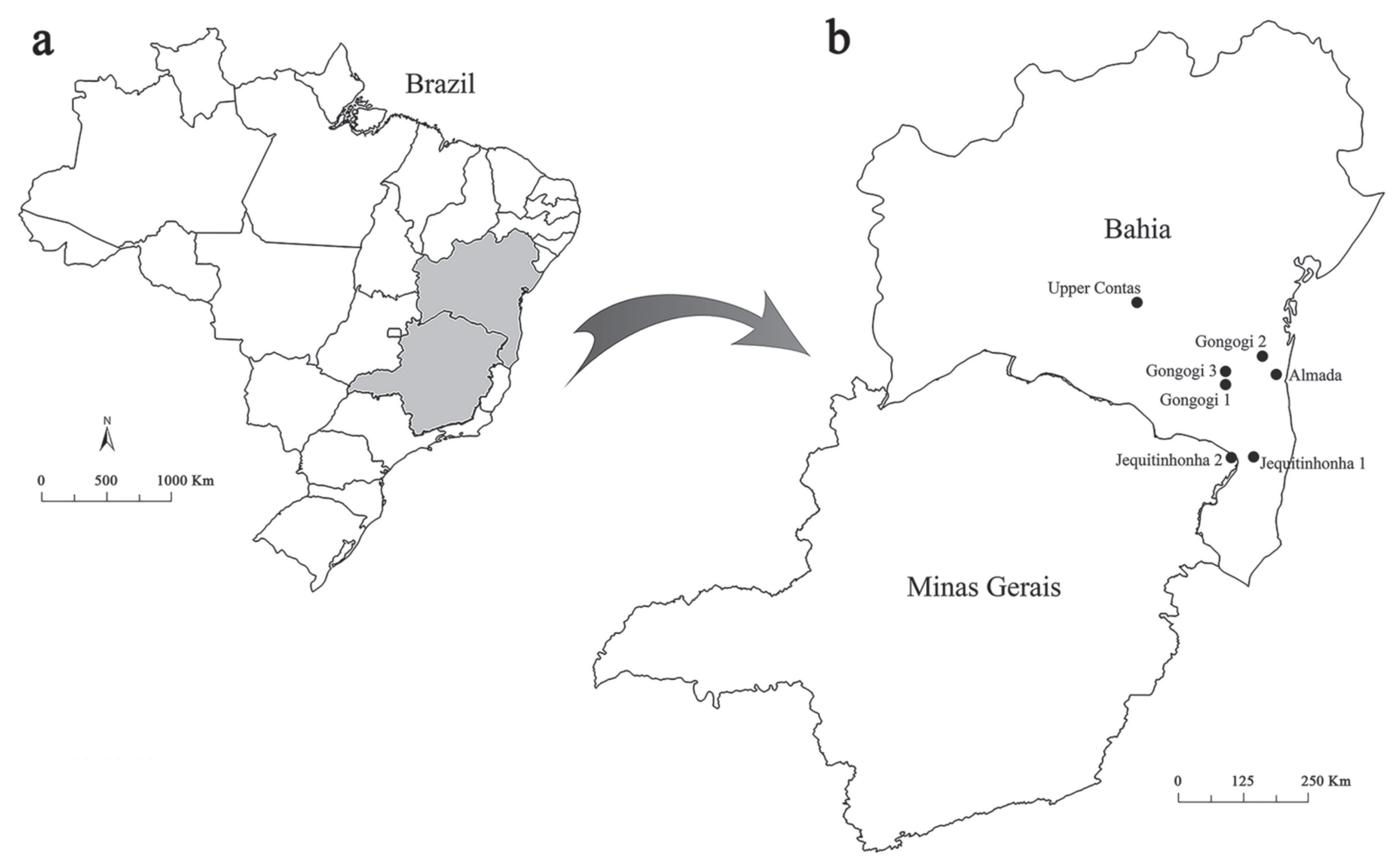

Fig. 1. Map of Brazil (a) and collection sites (b) of Nematocharax venustus along the Almada (Almada), Contas (Upper Contas, Gongogi 1, 2, and 3), and Jequitinhonha River basins (Jequitinhonha 1 and 2) in the states of Bahia and Minas Gerais. 
Table 1. Collection sites and sampling of Nematocharax venustus from the Almada, Contas, and Jequitinhonha River basins. $\hat{O}=$ males and $Q=$ females .

\begin{tabular}{|c|c|c|c|}
\hline Collection site & Locality (basin) & Coordinates & Sample size (sex) \\
\hline Almada & Almada River (Almada River basin) & $14^{\circ} 39^{\prime} 31^{\prime \prime S} / 39^{\circ} 13^{\prime} 23^{\prime \prime} \mathrm{W}$ & $14(4 \hat{\jmath}, 10$ ㅇ $)$ \\
\hline Gongogi 1 & Tributary of Gongogi River (Contas River basin) & $14^{\circ} 49^{\prime} 56^{\prime \prime} \mathrm{S} / 40^{\circ} 06^{\prime} 12^{\prime \prime} \mathrm{W}$ & $16(7 ð,, 9+)$ \\
\hline Gongogi 2 & Tributary of Gongogi River (Contas River basin) & $14^{\circ} 20^{\prime} 33^{\prime \prime S} / 39^{\circ} 27^{\prime} 46^{\prime \prime} \mathrm{W}$ & $40\left(19 \jmath^{\lambda}, 21+\right.$ ) \\
\hline Gongogi 3 & Cambiriba Stream (Contas River basin) & $14^{\circ} 36^{\prime} 16^{\prime \prime} \mathrm{S} / 40^{\circ} 06^{\prime} 08^{\prime \prime} \mathrm{W}$ & $12\left(5 \jmath^{\lambda}, 7\right.$ 우 $)$ \\
\hline Upper Contas & Água Suja River (Contas River basin) & $13^{\circ} 24^{\prime} 34^{\prime \prime S} / 41^{\circ} 38^{\prime} 01^{\prime \prime} \mathrm{W}$ & $23(15 \hat{\jmath}, 8$ ㅇ $)$ \\
\hline Jequitinhonha 1 & Limoeiro River (Jequitinhonha River basin) & $16^{\circ} 05^{\prime} 09^{\prime \prime} \mathrm{S} / 39^{\circ} 37^{\prime} 09^{\prime \prime} \mathrm{W}$ & $14\left(8 \jmath^{\lambda}, 6\right.$ ㅇ $)$ \\
\hline Jequitinhonha 2 & Jequitinhonha River (Jequitinhonha River basin) & $16^{\circ} 05^{\prime} 41^{\prime \prime S} / 40^{\circ} 00^{\prime} 05^{\prime \prime} \mathrm{W}$ & $22(13 \hat{\jmath}, 9$ 우 \\
\hline
\end{tabular}

The collection license was provided by Instituto Chico Mendes de Conservação da Biodiversidade (ICMBio; license number SISBIO 39728-1). Voucher specimens were stored in the fish collection from the Museu de Zoologia da Universidade Federal da Bahia (MZUFBA), Brazil (UFBA 7953, 7954, 8016, 8017, 8018, 8019, and 8020).

The specimens were transported to aerated tanks, and mitotic chromosomes were obtained from kidney cells according to Netto et al. (2007) and Blanco et al. (2012) after mitotic stimulation for $48 \mathrm{~h}$ (Lee \& Elder, 1980). All experimental procedures and euthanasia of specimens were previously authorized by the Comitê de Ética em Uso de Animais da Universidade Estadual do Sudoeste da Bahia (CEUA/UESB, number 32/2013).

For karyotyping, the chromosomes were classified into metacentric (m), submetacentric (sm), subtelocentric (st) and acrocentric (a), according to Levan et al. (1964). The active nucleolar organizer regions (Ag-NORs) were detected by silver nitrate staining (Howell \& Black, 1980) and heterochromatin segments were visualized by C-banding (Sumner, 1972). Base-specific fluorochrome staining using Chromomycin $\mathrm{A}_{3}\left(\mathrm{CMA}_{3}\right)$ and 4'6-diamidino-2phenylindole (DAPI) were applied to detected GC- and AT-rich regions, respectively (Schweizer, 1980).

Two repetitive DNA sequences isolated from Hoplias malabaricus (Bloch, 1794) were used as probes in FISH. The first probe comprised the 5S rDNA, which included 120 base pairs (bp) of coding sequence and $200 \mathrm{bp}$ of non-transcribed spacer (Martins et al., 2006). The second probe corresponded to a segment of $1,400 \mathrm{bp}$ of $18 \mathrm{~S}$ rDNA obtained by Polymerase Chain Reaction (PCR) (Cioffi et al., 2009a). Both probes were cloned in plasmidial vectors and propagated in competent cells of Escherichia coli DH5 $\alpha$ (Invitrogen, San Diego, CA, USA). The 5S and $18 \mathrm{~S}$ rDNA probes were labeled by nick translation with biotin16-dUTP and digoxigenin-11-dUTP, respectively, following manufacturer's instructions (Roche, Mannheim, Germany).

The FISH experiments were performed as described by Pinkel et al. (1986), using both probes simultaneously (double-FISH) under high stringency conditions (77\%). The $5 \mathrm{~S}$ rDNA probe was detected by conjugated fluorescein isothiocyanate-avidin (avidin-FITC) (Sigma, St. Louis, MO, USA) while the $18 \mathrm{~S}$ rDNA signals were detected by antidigoxigenin-Rhodamine conjugate (Roche, Mannheim,
Germany). The chromosomes were counterstained with DAPI $(1.2 \mu \mathrm{g} / \mathrm{ml})$ in antifading solution (Vector, Burlingame, CA, USA) and analyzed under an epifluorescent microscope Olympus BX51 (Olympus Corporation, Ishikawa, Japan). The images were captured using the software CoolSNAPPro (Media Cybernetics).

\section{Results}

All specimens, independently on collection site or sex, shared a diploid number of $2 \mathrm{n}=50$ with karyotypes composed of $8 m+26 s m+14 s t+2 a$ (Fig. 2). The heterochromatin was preferentially distributed at pericentromeric regions of submetacentric and subtelocentric chromosomes in most populations (Fig. 3a). However, the samples from the Upper Contas River were characterized by the presence of C-bands at terminal regions of pairs 11 and 18 (Fig. 3b).

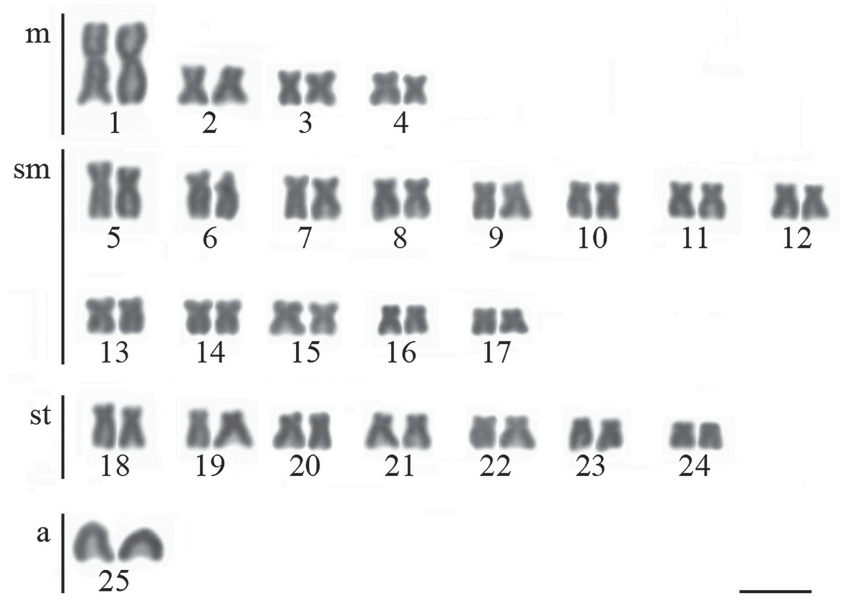

Fig. 2. Representative karyotype of Nematocharax venustus. $\mathrm{Bar}=5 \mu \mathrm{m}$.

Invariably, Ag-NORs in N. venustus were detected at terminal regions on short arms of a single pair. Yet, the NORbearing pair differed among populations, since the Ag-NORs in specimens from the Upper Contas River were interspersed with C-bands on pair 18 (st) while the remaining samples revealed active ribosomal regions on pair 8 (sm) (Fig. 4). Likewise, $\mathrm{GC}$-rich regions ( $\mathrm{CMA}_{3}^{+}$and DAPI) were observed in a single pair, being equivalent to Ag-NORs (Fig. 4). 
a

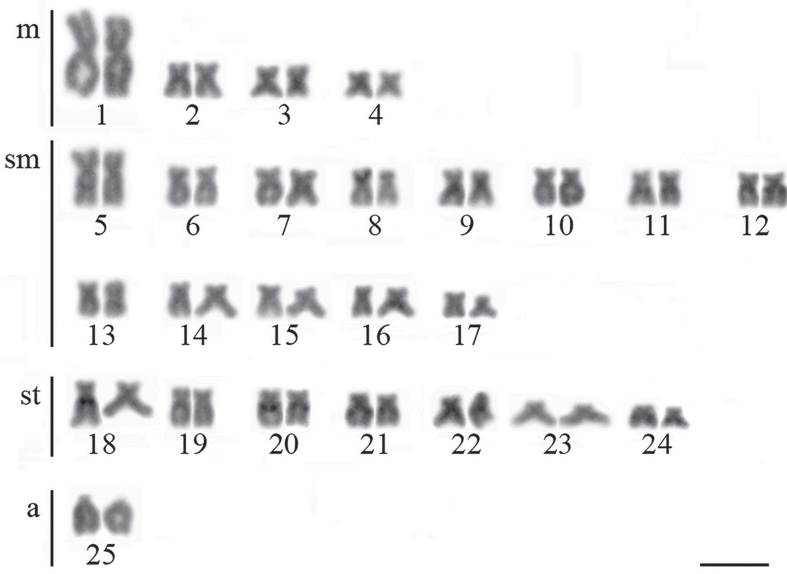

b
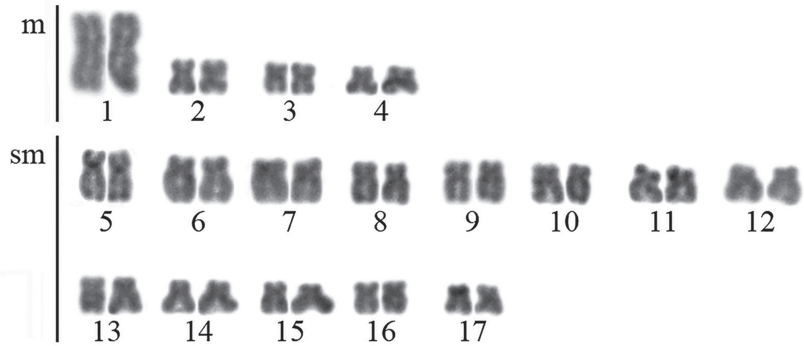

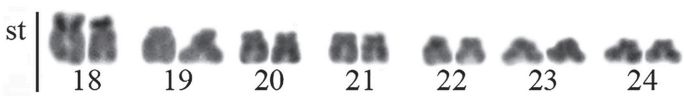

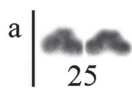

Fig. 3. Representative C-banded karyotypes of Nematocharax venustus from (a) Almada, Gongogi 1, Gongogi 2, Gongogi 3, Jequitinhonha 1, Jequitinhonha 2 and (b) Upper Contas. Bar $=5 \mu \mathrm{m}$.

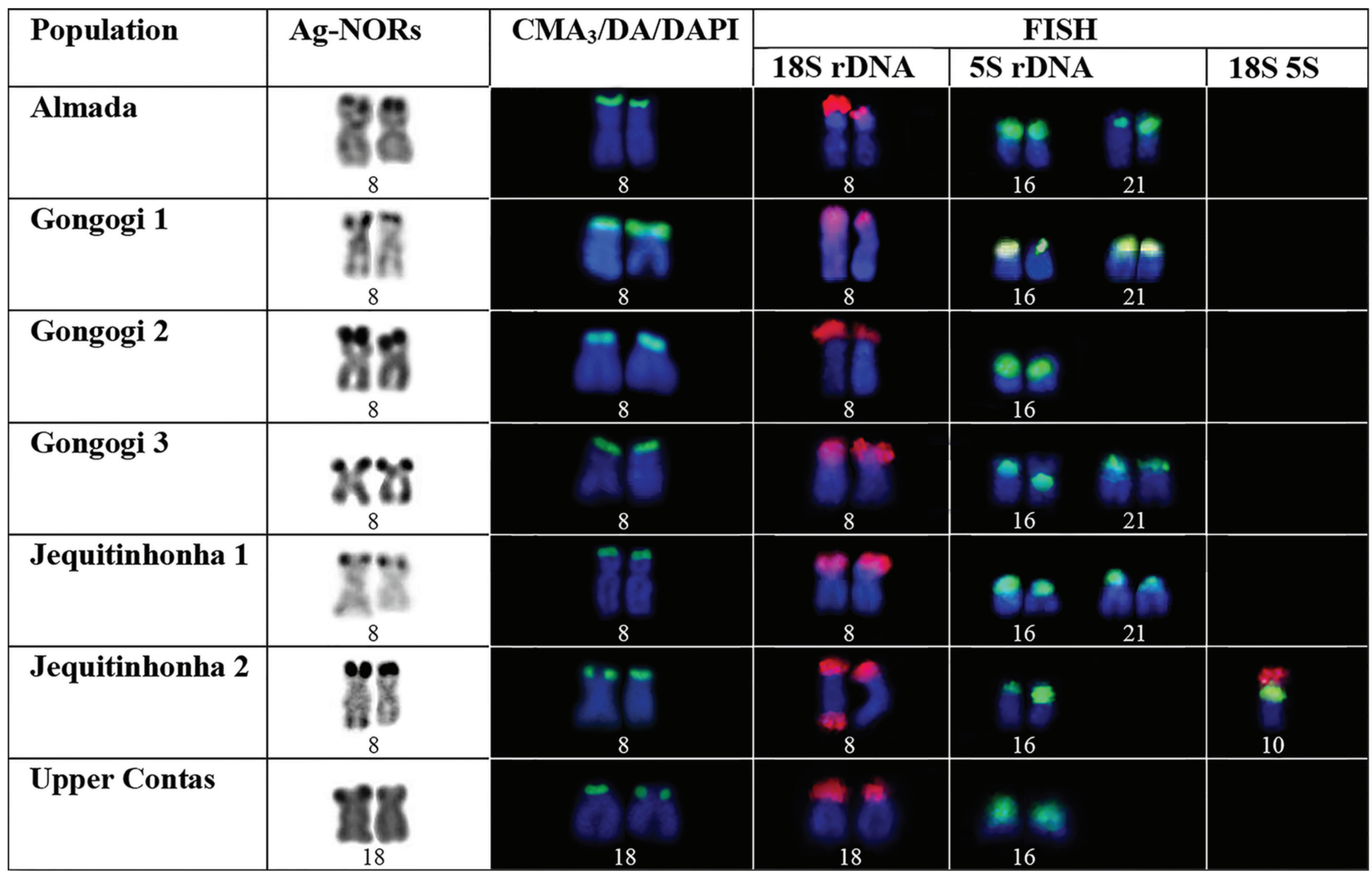

Fig. 4. Chromosomes of distinct populations of Nematocharax venustus after silver nitrate staining (Ag-NORs), base-specific fluorochrome staining $\left(\mathrm{CMA}_{3} / \mathrm{DA} / \mathrm{DAPI}\right)$ and FISH with $18 \mathrm{~S}$ (magenta) and $5 \mathrm{~S}$ rDNA probes (green). $\mathrm{Bar}=5 \mu \mathrm{m}$.

The FISH with ribosomal probes confirmed the occurrence of a single NOR system in most populations. The only exception refers to one sample in the Jequitinhonha River basin (named Jequitinhonha 2), which presented additional 18S rDNA sites on long arms in one homologous from pair 8 and on short arms of a single chromosomes from pair 10. This procedure was also informative in revealing four distribution patterns of $18 \mathrm{~S}$ and $5 \mathrm{~S}$ rDNA in N. venustus (Fig. 4).
The first pattern, shared by specimens from the Almada River and some populations from the Contas (Gongogi 1) and Jequitinhonha River basins (Jequitinhonha 1), includes 18S rRNA genes at terminal region of short arms of a sm pair (equivalent to Ag-NORs) and 5S rRNA genes at interstitial region on short arms of two pairs $(16-\mathrm{sm}$, and $21-\mathrm{st}$ ). The population from Gongogi 3 differs from this pattern by presenting heteromorphic 5S rDNA cistrons 
in pair 16 , located at interstitial position on short arms of one chromosome and at pericentromeric region in the homologous (Fig. 4). The second pattern was similar that abovementioned, being observed in the population named as Gongogi 2. The only difference in this case refers to the presence of a single pair (16) bearing 5S rDNA at interstitial position on short arms (Fig. 4).

The population identified as Jequitinhonha 2 was characterized by a unique distribution of ribosomal genes, including bitelomeric 18S rDNA signals in one chromosome from pair 8. Moreover, this sample presented syntenic location of $18 \mathrm{~S}$ and $5 \mathrm{~S}$ rDNAs on short arms of one homologous from pair 10, being the latter closer to the centromeric region (Fig. 4). Another differential pattern was verified in the population from the Upper Contas River, since the specimens from this locality showed $18 \mathrm{~S}$ rDNA sites on short arms of pair 18 while 5S rDNA regions were located interstitially on short arms of a single sm pair (16) (Fig. 4). The double-FISH metaphases for each different pattern observed, followed by the same metaphases stained with DAPI only, are shown in Figure 5.

\section{Discussion}

In spite of being the most cytogenetically studied group of Neotropical ichthyofauna (Nirchio et al., 2014), karyotypic data are still absent for many species and genera of Characiformes, such as Nematocharax. The karyotype macrostructure of $N$. venustus, including the modal diploid number of $2 n=50$, high number of biarmed chromosomes and a large metacentric pair ( $1^{\text {st }}$ pair), is observed in several species of Characidae. For instance, this pattern has been reported in Astyanax scabripinnis (Jenyns, 1842) (Moreira Filho \& Bertollo, 1991), Hasemania nana (Lütken, 1875) (Moreira et al., 2007), Hyphessobrycon anisitsi (Eigenmann, 1907) (Mendes et al., 2011), Hollandichthys multifasciatus (Eigenmann \& Norris, 1900) (Balen et al., 2013) and Rhoadsia altipinna Fowler, 1911 (Romero et al., 2015), being considered a plesiomorphic condition of characins (Scheel, 1973; Morelli et al., 1983). The presence of distinct types of chromosomes ( $\mathrm{m}, \mathrm{sm}, \mathrm{st}$, and a) without variation in diploid number suggests the occurrence of pericentric inversions, another common rearrangement in characins (Medrado et al., 2015).

In the case of taxa with similar chromosomal number and morphology, the analysis of heterochromatin distribution might be helpful to provide cytotaxonomic or population markers, as previously shown in other Characiformes (Galetti Júnior et al., 1991; Mantovani et al., 2000; Jacobina et al., 2009). However, the C-bands were restricted to pericentromeric region and NORs in most populations of $N$. venustus, following a common trend in fish (Imai, 1991; Aguilar \& Galetti Júnior, 2008; Rosa et al., 2009). The only exception was the population from the Upper Contas River, which presented terminal heterochromatic segments in two pairs (Fig. 3b). This unique C-banding pattern indicates that this population is genetically divergent, as further discussed.

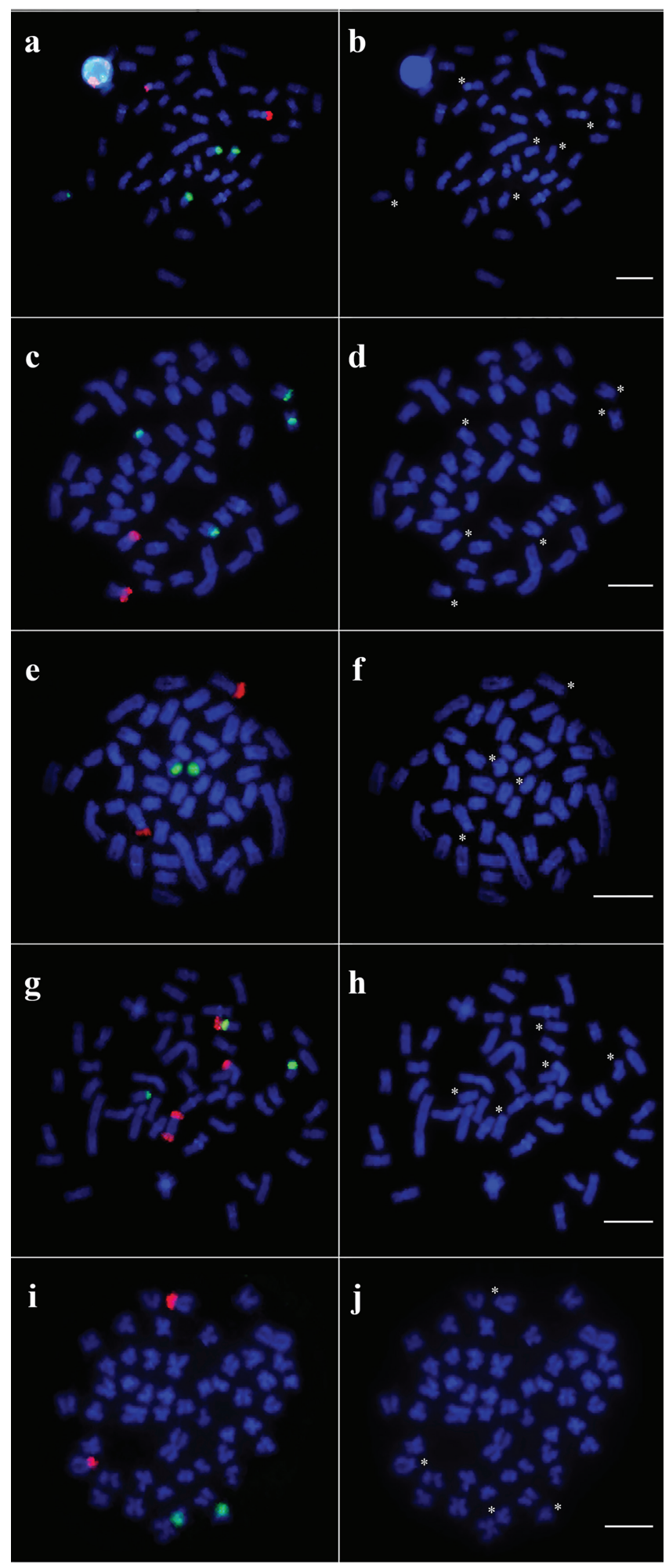

Fig. 5. Representative metaphases for each different pattern reported in populations of Nematocharax venustus showing the hybridization with $18 \mathrm{~S}$ (magenta) and $5 \mathrm{~S}$ rDNA probes (green) (double-FISH) and only DAPI staining for (a, b) Almada, Gongogi 1, and Jequitinhonha 1; (c, d) Gongogi 3; (e, f) Gongogi 2; (g, h) Jequitinhonha 2 ; and (i, j) Upper Contas. The asterisks indicate the chromosomes marked by FISH. Bars $=5 \mu \mathrm{m}$. 
On the other hand, microstructural interpopulation differences were observed by mapping the ribosomal genes in $N$. venustus, particularly in relation to the samples from Jequitinhonha 2 and Upper Contas. Even though most populations presented active rDNA sites interspersed with GC-rich sites $\left(\mathrm{CMA}_{3}^{+}\right)$, a common feature in fish (e.g., Verma et al., 2011; Santos et al., 2012), additional 18S rDNA cistrons were identified by FISH in specimens from Jequitinhonha 2, characterizing a multiple NOR system. In the case of individuals from Upper Contas, the NORs were located on the first st pair while submetacentric NOR-bearing pairs were observed in the other populations of $N$. venustus (Fig. 4). Thus, the distribution of $18 \mathrm{~S}$ rDNA cistrons apparently represents cytogenetic markers for the populations from the Contas River basin.

These results corroborate the dynamic evolution of NORs in Characidae (Galetti Júnior, 1998). Indeed, even though some genera of Characidae share single NORs, a basal condition in teleosteans (Gornung, 2013), as reported in Tetragonopterus Cuvier (Alberdi \& Fenocchio, 1997), Moenkhausia Eigenmann (Castro \& Júlio Júnior, 2002), Bryconamericus Eigenmann (Marques et al., 2003) and Piabina Reinhardt (Pazian et al., 2012), most species in this family present multiple NORs (Kavalco \& Moreira Filho, 2003).

The remarkable variation of both position and number of ribosomal sites in characins and other Characiformes might reflect the polyphyletism of this fish group (Peres et al., 2008) and/or the association of rDNA with transposable elements (TE) that mobilize adjacent ribosomal sequences (Cioffi et al., 2010). Reinforcing the polymorphic nature of rRNA genes in Characidae, the mapping of $18 \mathrm{~S}$ and $5 \mathrm{~S}$ rDNA by FISH revealed clear interpopulation cytogenetic divergence in $N$. venustus.

Usually, the $18 \mathrm{~S}$ and $5 \mathrm{~S}$ rDNA sites in Neotropical fish are located on distinct chromosomal pairs (Galetti Júnior \& Martins, 2004). This pattern was observed in most populations but Jequitinhonha 2, since doubleFISH revealed syntenic $18 \mathrm{~S}$ and $5 \mathrm{~S}$ rDNA cistrons in a homologous from pair 10 (Fig. 4). However, this characteristic may be an intrapopulation variation found in Jequitinhonha 2, since the double-FISH was obtained for a single individual from this collection site. Other reports of synteny between both families of ribosomal genes are available in some genera of Characiformes, like Astyanax Baird \& Girard (Castro et al., 2014b), Prochilodus Agassiz (Vicari et al., 2006), Triportheus Cope (Diniz et al., 2009), and Hoplias Gill (Cioffi et al., 2009b). It should be pointed out that active Ag-NORs in the population from Jequitinhonha 2 were observed only in pair 8. Nonetheless, syntenic ribosomal genes were detected by FISH in one chromosome from pair 10. The lack of hybridization signal in the other homologous could indicate differences in the number of copies for this gene between chromosomes of pair 10 possibly related to unequal exchanges.
In addition, the location of $18 \mathrm{~S}$ rDNA sites at terminal chromosomal regions is widespread in teleosteans. Apparently, this behavior favors the rearrangement of NORs without interfering with other genetic linkage groups (Hanson et al., 1996), besides promoting the redistribution of ribosomal genes by the proximity of telomeres in the interphasic nuclei (Gornung, 2013). Such distribution of 18S rRNA genes in $N$. venustus could account for the putative transposition of some copies of this rDNA in one homologous of pair 8 in the population from Jequitinhonha 2, giving rise to the bitelomeric NORs (Fig. 4). Again, the presence of $18 \mathrm{~S}$ rDNA sites in both telomeres have already been reported in other Characiformes characterized by accentuated chromosomal variation, such as $A$. fasciatus (Cuvier, 1819) (Fernandes et al., 2009), A. scabripinnis (Mantovani et al., 2005), A. hastatus Myers, 1928 (Kavalco et al., 2009), and H. malabaricus (Cioffi et al., 2009a).

Differently from $18 \mathrm{~S}$ rDNA, the $5 \mathrm{~S}$ rDNA sites in fish are usually located at interstitial and euchromatic chromosomal regions (Martins \& Galetti Júnior, 2001), as reported in $N$. venustus. This condition seems to reduce the genomic dispersal and reorganization of 5S rRNA genes when compared to NORs (Martins \& Wasko, 2004). Nonetheless, a possible heterozygous pericentric inversion, encompassing the 5S rDNA cluster, is suggested for the heteromorphic pair 16 in individuals from Gongogi 3 (Fig. 4), thereby explaining the differential position of $5 \mathrm{~S}$ rDNA signals between homologous. Moreover, numerical variation of $5 \mathrm{~S}$ rDNA signals was also detected in the present study. While most populations of $N$. venustus shared two pairs bearing 5S rRNA genes, as commonly reported in characins (Kavalco et al., 2011), the individuals from Gongogi 2 and Upper Contas were characterized by a single $5 \mathrm{~S}$ rDNA-bearing pair. These data show the importance of refined methodologies of chromosomal mapping in revealing chromosomal rearrangements that otherwise would remain imperceptible, mainly due to the homogeneous macrokaryotypic structure in this species.

Along with the cytogenetic particularities, the specimens from the Upper Contas River, in Diamantina Plateau, are also morphologically distinctive once they present slender bodies and short rays in pelvic fins of males (data not shown), being likely to correspond to a new and undescribed species of Nematocharax. Reproductive isolation and speciation in the Upper Contas River are favored by the geological processes in the eastern region of Brazil, which includes the Diamantina Plateau and the Espinhaço Hills (Derby, 1906). In fact, divergent species associated to the isolation promoted by these biogeographic barriers have been reported even in animals of high dispersal potential, like birds (Vasconcelos et al., 2012).

Furthermore, karyotypic novelties can evolve independently within relatively short periods in populations of small characins, like $N$. venustus, because their restricted dispersal and short life cycles (Castro, 1999) lead to reduced gene flow and rapid establishment of chromosomal 
rearrangements (Centofante et al., 2006; Pazza \& Kavalco, 2007). Therefore, isolated and small populations in headwaters, like the one from the Upper Contas River, are more susceptible to genetic drift effects, potentially leading to the fixation of unique chromosomal features at random. Similarly, the populations of $N$. venustus from the Jequitinhonha River basin are endangered due to the increased human activities (Menezes \& Lima, 2008), which might have reduced their effective population sizes. Thus, inbreeding and genetic drift effects related to bottleneck events might have increased the probability of fixing distinct chromosomal variants (Hedrick, 1981).

In conclusion, the present results increase the karyotypic reports in characins from coastal basins in Eastern Atlantic, a region recognized by high levels of endemism combined with severe human impacts (Camelier \& Zanata, 2014). The comparative cytogenetic analysis provided evidence of allopatric chromosomal variation in $N$. venustus along its range, suggesting the presence of populations with distinct evolutionary histories that should be further investigated using other genetic markers. Otherwise, species or structured populations can be lost because they lack appropriate conservation management plans.

\section{Acknowledgements}

The authors are grateful to Fundação de Amparo à Pesquisa do Estado da Bahia (FAPESB) for the financial support (grants PNE0019/2011, and RED0009/2013) and Instituto Chico Mendes de Conservação da Biodiversidade (ICMBio) for authorizing the collection of specimens.

\section{References}

Aguilar, C. T. \& P. M. Galetti Júnior. 2008. Chromosome mapping of 5S rRNA genes differentiates Brazilian populations of Leporellus vittatus (Anostomidae, Characiformes). Genetics and Molecular Biology, 31: 188-194.

Alberdi, A. J. \& A. S. Fenocchio. 1997. Karyotypes of five Tetragonopterinae species (Pisces, Characidae) from Argentina. Cytologia, 62: 171-176.

Almeida, J. S., P. R. A. M. Affonso, D. Diniz, P. L. S. Carneiro \& A. L. Dias. 2013. Chromosomal variation in the tropical armored catfish Callichthys callichthys (Siluriformes, Callichthyidae): implications for conservation and taxonomy in a species complex from a Brazilian hotspot. Zebrafish, 10: 451-458.

Balen, R. E., R. B. Noleto, M. R. Vicari, R. F. Artoni \& M. M. Cestari. 2013. Comparative cytogenetics among populations of Hollandichthys multifasciatus (Teleostei: Characidae). Zoological Science, 30: 105-109.

Bellafronte, E., M. O. Schemberger, O. Moreira Filho, M. C. Almeida, R. F. Artoni, V. P. Margarido \& M. R. Vicari. 2010. Chromosomal markers in Parodontidae: an analysis of new and reviewed data with phylogenetic inferences. Reviews in Fish Biology and Fisheries, 21: 559-570.
Bitencourt, J. A., P. R. A. M. Affonso, L. Giuliano-Caetano \& A. L. Dias. 2011. Identification of distinct evolutionary units in allopatric populations of Hypostomus cf. wuchereri Günther, 1864 (Siluriformes: Loricariidae): karyotypic evidence. Neotropical Ichthyology, 9: 317-324.

Blanco, D. R., L. A. C. Bertollo, R. L. Lui, M. R. Vicari, V. P. Margarido, R. F. Artoni \& O. Moreira Filho. 2012. A new technique for obtaining mitotic chromosome spreads from fishes in the field. Journal of Fish Biology, 81: 351-357.

Blanco, D. R., R. L. Lui, L. A. C. Bertollo, V. P. Margarido \& O. Moreira Filho. 2010. Karyotypic diversity between allopatric populations of the group Hoplias malabaricus (Characiformes: Erythrinidae): evolutionary and biogeographic considerations. Neotropical Ichthyology, 8: 361-368.

Bragança, P. H. N., M. A. Barbosa \& J. L. Mattos. 2013. A new Nematocharax species from the middle Contas River basin, Northeastern Brazil (Characiformes: Characidae). Vertebrate Zoology, 63: 3-8.

Camelier, P. \& A. M. Zanata. 2014. Biogeography of freshwater fishes from the Northeastern Mata Atlântica freshwater ecoregion: distribution, endemism, and area relationships. Neotropical Ichthyology, 12: 683-698.

Castro, A. L. B. P. \& H. F. Júlio Júnior. 2002. Karyotype relationships among species of the subfamily Tetragonopterinae (Pisces, Characidae): cytotaxonomy and evolution aspects. Cytologia, 67: 329-336.

Castro, J. P., M. O. Moura, O. Moreira Filho, O. A. Shibatta, M. H. Santos, V. Nogaroto, M. R. Vicari, M. C. Almeida \& R. F. Artoni. 2014a. Diversity of the Astyanax scabripinnis species complex (Teleostei: Characidae) in the Atlantic Forest, Brazil: species limits and evolutionary inferences. Reviews in Fish Biology and Fisheries, 25: 231-244.

Castro, J. P., M. O. Moura, O. Moreira Filho, O. A. Shibatta, M. H. Santos, V. Nogaroto, M. R. Vicari, M. C. Almeida \& R. F. Artoni. 2014b. Evidence of incipient speciation in Astyanax scabripinnis species complex (Teleostei: Characidae). Neotropical Ichthyology, 12: 429-438.

Castro, R. M. C. 1999. Evolução da ictiofauna de riachos sulamericanos: padrões gerais e possíveis processos causais. Pp. 139-155. In: Caramaschi, E. P., R. Mazzoni \& P. R. Peres Neto (Eds.). Ecologia de peixes de riachos. Rio de Janeiro, Programa de Pós-Graduação em Ecologia, Instituto de Biologia, Universidade Federal do Rio de Janeiro. (Oecologia Brasiliensis, v. 6).

Centofante, L., L. A. C. Bertollo \& O. Moreira Filho. 2006. Chromosomal differentiation between populations of Oligosarcus hepsetus (Teleostei, Characidae) from small tributaries at opposite margins of the Paraiba do Sul River (Brazil). Brazilian Archives of Biology and Technology, 49: 981-987.

Cioffi, M. B., C. Martins \& L. A. C. Bertollo. 2009a. Comparative chromosome mapping of repetitive sequences. Implications for genomic evolution in the fish, Hoplias malabaricus. BMC Genetics, 10: 34(11p.).

Cioffi, M. B., C. Martins \& L. A. C. Bertollo. 2010. Chromosome spreading of associated transposable elements and ribosomal 
DNA in the fish Erythrinus erythrinus. Implications for genome change and karyoevolution in fish. BMC Evolutionary Biology, 10: 271 (9p.).

Cioffi, M. B., C. Martins, L. Centofante, U. Jacobina \& L. A. C. Bertollo. 2009b. Chromosomal variability among allopatric populations of Erythrinidae fish Hoplias malabaricus: mapping of three classes of repetitive DNAs. Cytogenetic and Genome Research, 125: 132-141.

Derby, O. A. 1906. The Serra do Espinhaço, Brazil. The Journal of Geology, 14: 374-401.

Diniz, D., A. Laudicina \& L. A. C. Bertollo. 2009. Chromosomal location of $18 \mathrm{~S}$ and $5 \mathrm{~S}$ rDNA sites in Triportheus fish species (Characiformes, Characidae). Genetics and Molecular Biology, 32: 37-41.

Eschmeyer, W. N. \& J. D. Fong. 2015. Species by family/ subfamily. Species by family/subfamily in the catalog of fishes. Available from: http://researcharchive.calacademy. org/research/ichthyology/catalog/speciesbyfamily.asp. (05 February 2016).

Fernandes, C. A., I. C. Martins Santos \& D. Bailly. 2009. Karyotype analysis and mapping of the $18 \mathrm{~S}$ and $5 \mathrm{~S}$ ribosomal genes in Astyanax fasciatus (Teleostei, Characiformes) from Paranapanema river basin. Cytologia, 74: 295-300.

Galetti Júnior, P. M. 1998. Chromosome diversity in Neotropical fishes: NOR studies. Italian Journal of Zoology, 65(S1): 5356.

Galetti Júnior, P. M., A. C. G. Cesar \& P. C. Venere. 1991. Heterochromatin and NORs variability in Leporinus fish (Anostomidae, Characiformes). Caryologia, 44: 287-292.

Galetti Júnior, P. M. \& C. Martins. 2004. Contribuição da hibridização in situ para o conhecimento dos cromossomos de peixes. Pp. 61-88. In: Guerra, M. (Ed.). FISH: conceitos e aplicações na Citogenética. Ribeirão Preto, Sociedade Brasileira de Genética.

Gornung, E. 2013. Twenty years of physical mapping of major ribosomal RNA genes across the Teleosts: a review of research. Cytogenetic and Genome Research, 141: 90-102.

Hanson, R. E., M. N. Islam-Faridi, E. A. Percival, C. F. Crane, Y. Ji, T. D. McKnight, D. M. Stelly \& H. J. Price. 1996. Distribution of $5 \mathrm{~S}$ and 18S-28S rDNA loci in a tetraploid cotton (Gossypium hirsutum L.) and its putative diploid ancestors. Chromosoma, 105: 55-61.

Hedrick, P. W. 1981. The establishment of chromosomal variants. Evolution, 322-332.

Howell, W. M. \& D. A. Black. 1980. Controlled silver-staining of nucleolus organizer regions with a protective colloidal developer: a 1-step method. Experientia, 36: 1014-1015.

Imai, H. T. 1991. Mutability of constitutive heterochromatin (C-bands) during eukaryotic chromosomal evolution and their cytological meaning. The Japanese Journal of Genetics, 66: 635-661.

Jacobina, U. P., P. R. A. M. Affonso, P. L. S. Carneiro \& J. A. Dergam. 2009. Biogeography and comparative cytogenetics between two populations of Hoplias malabaricus (Bloch, 1794) (Ostariophysi: Erythrinidae) from coastal basins in the State of Bahia, Brazil. Neotropical Ichthyology, 7: 617-622.
Kavalco, K. F., K. O. Brandão, R. Pazza \& L. F. A. Toledo. 2009. Astyanax hastatus Myers, 1928 (Teleostei, Characidae): a new species complex within the genus Astyanax? Genetics and Molecular Biology, 32: 477-483.

Kavalco, K. F. \& O. Moreira Filho. 2003. Cytogenetical analyses in four species of the genus Astyanax (Pisces, Characidae) from Paraíba do Sul River basin. Caryologia, 56: 453-461.

Kavalco, K. F., R. Pazza, K. O. Brandão, C. Garcia \& L. F. A. Toledo. 2011. Comparative cytogenetics and molecular phylogeography in the group Astyanax altiparanae - Astyanax aff. bimaculatus (Teleostei, Characidae). Cytogenetic and Genome Research, 134: 108-119.

Lee, M. R. \& F. F. B. Elder. 1980. Yeast stimulation of bone marrow mitosis for cytogenetic investigations. Cytogenetics and Cell Genetics, 26: 36-40.

Levan, A., K. Fredga \& A. A. Sandberg. 1964. Nomenclature for centromeric position on chromosomes. Hereditas, 52: 201-220.

Mantovani, M., L. D. S. Abel, C. A. Mestriner \& O. Moreira Filho. 2000. Accentuated polymorphism of heterochromatin and nucleolar organizer regions in Astyanax scabripinnis (Pisces, Characidae): tools for understanding karyotypic evolution. Genetica, 109: 161-168.

Mantovani, M., L. D. S. Abel \& O. Moreira Filho. 2005. Conserved $5 \mathrm{~S}$ and variable $45 \mathrm{~S}$ rDNA chromosomal localisation revealed by FISH in Astyanax scabripinnis (Pisces, Characidae). Genetica, 123: 211-216.

Marques, T. R. P., L. G. Caetano \& A. L. Dias. 2003. Cytogenetic characterization of a population of Bryconamericus aff. iheringii (Characidae, Tetragonopterinae). Genetics and Molecular Biology, 26: 145-149.

Martins, C., I. A. Ferreira, C. Oliveira, F. Foresti \& P. M. Galetti Júnior. 2006. A tandemly repetitive centromeric DNA sequence of the fish Hoplias malabaricus (Characiformes: Erythrinidae) is derived from 5S rDNA. Genetica, 127: 133-141.

Martins, C. \& P. M. Galetti Júnior. 2001. Two 5S rDNA arrays in Neotropical fish species: is it a general rule for fishes? Genetica, 111: 439-446.

Martins, C. \& A. P. Wasko. 2004. Organization and evolution of 5S ribosomal DNA in the fish genome. Pp. 335-363. In: Williams, C. R. (Ed.). Focus on genome research. Hauppauge, Nova Science Publishers.

Medrado, A. S., P. R. A. M. Affonso, P. L. S. Carneiro, M. R. Vicari, R. F. Artoni \& M. A. Costa. 2015. Allopatric divergence in Astyanax aff. fasciatus Cuvier, 1819 (Characidae, Incertae sedis) inferred from DNA mapping and chromosomes. Zoologischer Anzeiger, 257: 119-129.

Mendes, M. M., R. Rosa, L. G. Caetano \& A. L. Dias. 2011. Karyotype diversity of four species of the incertae sedis group (Characidae) from different hydrographic basins: analysis of AgNORs, CMA3 and 18S rDNA. Genetics and Molecular Research, 10: 3596-3608.

Menezes, N. A. \& F. C. T. Lima. 2008. Nematocharax venustus Weitzman, Menezes \& Britski, 1986. Pp. 85-86. In: Machado, A. B. M., G. M. Drummond \& A. P. Paglia (Eds.). Livro Vermelho da Fauna Brasileira Ameaçada de Extinção. Brasília, MMA. v. 2, 888p. 
Menezes, N. A., A. M. Zanata \& P. Camelier. 2015. Nematocharax costai Bragança, Barbosa \& Mattos a junior synonym of Nematocharax venustus Weitzman, Menezes \& Britski (Teleostei: Characiformes: Characidae). Zootaxa, 3920: 453462.

Moreira, P. W. A., L. A. C. Bertollo \& O. Moreira Filho. 2007. Comparative cytogenetics between three Characidae fish species from the São Francisco River basin. Caryologia, 60: 64-68.

Moreira Filho, O. \& L. A. C. Bertollo. 1991. Astyanax scabripinnis (Pisces, Characidae): a species complex. Revista Brasileira de Genética, 142: 331-357.

Morelli, S., L. A. C. Bertollo, F. Foresti, O. Moreira Filho \& S. A. Toledo Filho. 1983. Cytogenetic considerations on the genus Astyanax (Pisces, Characidae). I. Kariotypic variability. Caryologia, 36: 235-244.

Netto, M. R. C. B., E. Pauls \& P. R. A. M. Affonso. 2007. A standard protocol for obtaining fish chromosomes under postmortem conditions. Micron, 38: 214-217.

Nirchio, M., A. R. Rossi, F. Foresti \& C. Oliveira. 2014. Chromosome evolution in fishes: a new challenging proposal from Neotropical species. Neotropical Ichthyology, 12: 761-770.

Pazian, M. F., L. H. G. Pereira, C. K. S. Dias, C. Oliveira \& F. Foresti. 2012. Cytogenetic and molecular markers reveal the complexity of the genus Piabina Reinhardt, 1867 (Characiformes: Characidae). Neotropical Ichthyology, 10: 329-340.

Pazza, R. \& K. F. Kavalco. 2007. Chromosomal evolution in the Neotropical characin Astyanax (Teleostei, Characidae). The Nucleus, 50: 519-543.

Peres, W. A. M., L. A. C. Bertollo \& O. Moreira Filho. 2008. Physical mapping of the $18 \mathrm{~S}$ and $5 \mathrm{~S}$ ribosomal genes in nine Characidae species (Teleostei, Characiformes). Genetics and Molecular Biology, 31(S1): 222-226.

Pinkel, D., T. Straume \& J. W. Gray. 1986. Cytogenetic analysis using quantitative, high-sensitivity, fluorescence hybridization. Proceedings of the National Academy of Sciences of the United States of America, 83: 2934-2938.

Piscor, D., A. L. Alves \& P. P. P. Maltempi. 2015. Chromosomal microstructure diversity in three Astyanax (Characiformes, Characidae) species: comparative analysis of the chromosomal locations of the 18S and 5S rDNAs. Zebrafish, 12: 81-90.

Romero, O. S., C. Q. Abad, P. Q. Cordero, V. F. Sene, M. Nirchio \& C. Oliveira. 2015. First description of the karyotype and localization of major and minor ribosomal genes in Rhoadsia altipinna Fowler, 1911 (Characiformes, Characidae) from Ecuador. Comparative Cytogenetics, 9: 271-280.

Rosa, R., M. Rubert, L. R. Malabarba, I. C. M. Santos \& L. G. Caetano. 2009. Cytogenetic analysis of Astyanax laticeps (Cope, 1894) (Ostariophysi: Characidae) from the laguna dos Patos system. Neotropical Ichthyology, 7: 601-605.

Santos, A. R., M. Rubert, L. G. Caetano \& A. L. Dias. 2012. Sympatric occurrence of four cytotypes and one extra chromosome in Bryconamericus ecai (Characidae): 18S rDNA polymorphism and heterochromatin composition. Hereditas, 149: 24-33.
Scheel, J. J. 1973. Fish chromosomes and their evolution. Charlottenlund, Internal report of Danmarks Akvarium. 22p.

Schweizer, D. 1980. Simultaneous fluorescent staining of R bands and specific heterochromatic regions (DA-DAPI bands) in human chromosomes. Cytogenetics and Cell Genetics, 27: 190-193.

Sumner, A. T. 1972. A simple technique for demonstrating centromeric heterochromatin. Experimental Cell Research, 75: 304-306.

Utsunomia, R., J. C. P. Alves, G. J. C. Silva, F. F. Mendonça, P. C. Scacchetti, C. Oliveira \& F. Foresti. 2014. Molecular and cytogenetic analyses of cryptic species within the Synbranchus marmoratus Bloch, 1795 (Synbranchiformes: Synbranchidae) grouping: species delimitations, karyotypic evolution and intraspecific diversification. Neotropical Ichthyology, 12: 903-911.

Vari, R. P. \& L. R. Malabarba. 1998. Neotropical Ichthyology: an overview. Pp. 1-11. In: Malabarba, L. R., R. E. Reis, R. P. Vari, Z. M. S. Lucena \& C. A. S. Lucena (Eds.). Phylogeny and classification of Neotropical fishes. Porto Alegre, Edipucrs, 603p.

Vasconcelos, M. F., A. V. Chaves \& F. R. Santos. 2012. First record of Augastes scutatus for Bahia refines the location of a purported barrier promoting speciation in the Espinhaço range, Brazil. Revista Brasileira de Ornitologia, 20: 443-446.

Verma, J., W. S. Lakra, B. Kushwaha, M. Sirajuddin, N. S. Nagpure \& R. Kumar. 2011. Characterization of two freshwater silurid catfish using conventional and molecular cytogenetic techniques. Journal of Genetics, 90: 319-322.

Vicari, M. R., M. C. Almeida, L. A. C. Bertollo, O. Moreira Filho \& R. F. Artoni. 2006. Cytogenetic analysis and chromosomal characteristics of the polymorphic $18 \mathrm{~S}$ rDNA in the fish Prochilodus lineatus (Characiformes, Prochilodontidae). Genetics and Molecular Biology, 29: 621-625.

Weitzman, S. H. \& W. L. Fink. 1983. Relationships of the neon tetras, a group of South American freshwater fishes (Teleostei, Characidae), with comments on the phylogeny of New World Characiforms. Bulletin of the Museum of Comparative Zoology, 150: 339-395.

Weitzman, S. H., N. A. Menezes \& H. A. Britski. 1986. Nematocharax venustus, a new genus and species of fish from the rio Jequitinhonha, Minas Gerais, Brazil (Teleostei: Characidae). Proceedings of the Biological Society of Washington, 99: 335-346.
Submitted September 14, 2015 Accepted April 11, 2016 by Alexandre Hilsdorf 